\title{
Scientiiic and practical problems related to the calculation of hydrodynamic parameters of seepage through earth dams
}

\author{
by Dr. G. Kovacs *
}

\begin{abstract}
One of the most important problems when designing earth dams is to consider all the effects caused by water percolating through the body of the dam. For this purpose the following main hydrodynamical parameters of the seepage have to be determined: discharge, pressure head, velocity.

There are many methods proposed in the literature for calculating the special values of the parameters listed previously. The large scattering of their results indicates, however, the high uncertainties in and the unsufficient theoretical bases of the methods.

By studying the velocity or gradient hodographs three essential flow-and boundary conditions generally neglected in the previous classical theories can be determined. These are as follows:

-In the vicinity of the singular point the velocity tends to infinity. It may be supposed, therefore, that it surpasses the upper limit of the validity zone of Darcy's law, and thus the linear relationship between velocity and hydraulic gradient cannot be accepted for the whole seepage field.

- The intersection of the phreatic surface with the exit face cannot be identical with the intersection of the exit face and the level of the tailwater, the latter point being a singular point. There exists, therefore, a free exit surface, where the boundary condition is different from that below the tailwater.
\end{abstract}

- The modification of the flow pattern and that of the whole regime of seepage caused by capillarity should be aslo consirered, especially in cases, when capillary height is relatively high compared to the depth of the gravitational seepage field.

On the basis of theoretical analyses and laboratory experiments it can be stated that the necessity of the investigation of the non laminar seepage is very rare in the practice. The contradiction between this statement and the result of hodograph mapping might be explained by supposing that the flow field is a selfregulating system, in which the increase of velocity raises the resistance with higher power than unity. There exists, therefore, an upper finite limit of velocity, which cannot be surpassed at the exit face. This hypothesis seems to be proved by both conformal mapping and laboratory measurements, which indicate that the maximum exit velocity is independent of the geometrical parameters of the flow field.

The influence of the free exit surface can be well characterized by formulae previously derived, viz.:

- The position of the phreatic surface can be described by Dupuit's parabola using the height of the exit point as a lower boundary condition.

- Charnyi proved that the percolating discharge could be also calculated from the equation proposed by Dupuit, but for receiving accurate value-taking into account the effect of the free exit surface as well-the depth of the tailwater should be substituted as lower boundary condition, although this consideration of the boundary condition seems to be theoretically uncorrect. 
-Finally the height of the exit point can be determined from Polubarinova-Kochina's formula. The precondition of the validity of this relationship is that the discharge is equal to the value calculated from Dupuit's equation.

The laboratory experiments have shown discrepancy between the results of the relationships previously described and the data measured on models. The discharge surpasses the theoretical value only slightly, but the height of the exit point changes considerably with any modification of the flow rate. Investigating the capillary effect it was found that the whole difference between PolubarinovaKochina's theoretical curve and the measured data could be totaly explained by this phenomenon. Thus a unified system of relationships was developed to consider simultanously the effects of both capillarity and free exit face. The proposed equations are in good agreement with the results of laboratory experiments.

\section{Bibliography}

Aravin (V.J.) and Numerov (S. N.). - Theory of motion of liquids and gases in undeformable porous media (in Russian) Moscow (1953).

BeAR (J.), ZasLawsKy (D.) and Irmay (S.). - Physical principles of water percolation and seepage (in English). UNESCO, Arid Zone Research, XXIX (1968).

Casagrande (A.). - Seepage through dams (in English). Harward University, Soil Mechanics Series, No. 5 (1937).
Charny (I. A.). - The correct verification of Dupuit's formula in the case of unconfined seepage (in Russian). Dokl. Ak. Nauk of U.S.S.R. (1951), 6.

Kovács (G.). - The influence of the free exit surface on the discharge of seepage through dams with vertical faces (in Hungarian). Epités- és Közlekedésiudományi Közlemények (1965), 9.

Kovács (G.). - General Characterization of different types of seepage (in English), 13th Congress of I.A.H.R., Kyoto (1969, a).

Kovács (G.). - Relationship between velocity of seepage and hydraulic gradient in the zone of high velocity (in English). 13th Congress of I.A.H.R., Kyoto (1969, b).

Kovács (G.). - Characterization of steady seepage through homogeneous earth dams with vertical faces (in English). VITUKI Tanulmányok és Kutatási eredmények (1973).

Kozeny (J.). - Hydraulics (in German), Wien (1953).

McCorquodale (J. A.), NG (H. C.). - Non-Darcy flow solved by finite element analyses (in English). 13th Congress of I.A.H.R. Kyoto (1969)

Muskat (M.). - The flow of homogeneous fluids through porous media (in English). New York (1937).

NÉmeth (E.). - Hydromechanics (in Hungarian). Budapest (1963).

OKA (T.). - A study on the seepage around a sheet pile by applying Forchheimer's law (in English). 13th Congress of I.A.H.R. Kyoto (1969).

Pavlowsky (N. N.). - Collected studies (in Russian). Moscow, Leningrad (1956)

Polubarinova Kochina (P. Ja.). - Theory of groundwater movement (in Russian), Moscow (1952); (in English), Priceton (1962).

Schokı.ıсн, - Handbook of hydraulic structure (in German). Wien (1950).

THIRriot (C.). - Hydrodynamics of flow in porous media (in French). 13th Congress of I.A.H.R., Kyoto (1969). 